\title{
Edema Rating 2
}

National Cancer Institute

\section{Source}

National Cancer Institute. Edema Rating 2. NCI Thesaurus. Code C121312.

Moderate edema. 